\title{
HUBUNGAN LEMBAR KERJA PESERTA DIDIK BERBASIS CAT TERHADAP KEMAMPUAN PEMAHAMAN MATEMATIS SISWA
}

\author{
Patri Janson Silaban', Asnita Hasibuan² \\ 1,2Universitas Katolik Santo Thomas Medan, Indonesia \\ Email: patri_silaban280388@yahoo.co.id ${ }^{1}$, asnita_hasibuan@yahoo.co.id ${ }^{2}$
}

\begin{abstract}
To find out the development, effectiveness, relationship, response, enhancing the ability of mathematical understanding with the development of learner-based worksheets CAT six graders Methodist-12 field in the material integer arithmetic operations. This research is included in research and development (Research and Development). As that $R \& D$ is a research method used to produce certain products and test the effectiveness of these products. This method is used with the aim of developing CAT-based student worksheets for grade VI SD Methodist-12 Medan on integer arithmetic operations. The study found, namely (1) CAT-based Student Worksheets are feasible to be developed and good to be applied in learning, (2) CAT-based Student Worksheets have a positive and significant relationship with students' mathematical understanding abilities, (3) CAT-based Student Worksheets have a positive effect on students' mathematical understanding abilities. Teachers can create and present the teaching materials with exciting creativity, media with an attractive creativity, practice questions that are presented in accordance with the material, enhancing the creativity of teachers in designing learning media.
\end{abstract}

Keywords: CAT-based Student Worksheets, Mathematical Comprehension Ability.

\begin{abstract}
ABSTRAK
Untuk mengetahui perkembangan, efektivitas, hubungan, respon, peningkatan kemampuan pemahaman matematis peserta didik dengan pengembangan LKS kelasVI SD Methodist-12 bidang CAT pada materi operasi hitung bilangan bulat. Penelitian ini termasuk dalam penelitian dan pengembangan (Research and Development). Karena R\&D adalah metode penelitian yang digunakan untuk menghasilkan produk tertentu dan menguji keefektifan produk tersebut. Metode ini digunakan dengan tujuan untuk mengembangkan LKS berbasis CAT untuk siswa kelas VI SD Methodist-12 Medan pada operasi aritmatika bilangan bulat. Hasil penelitian menemukan, yaitu (1) LKS berbasis CAT layak untuk dikembangkan dan baik untuk diterapkan dalam pembelajaran, (2) LKS berbasis CAT memiliki hubungan yang positif dan signifikan dengan kemampuan pemahaman matematis siswa, (3) LKS berbasis CAT berpengaruh positif terhadap kemampuan pemahaman matematis siswa. Guru dapat menciptakan dan menyajikan bahan ajar dengan kreativitas yang menarik, media dengan kreativitas yang menarik, soal latihan yang disajikan sesuai dengan materi, meningkatkan kreativitas guru dalam mendesain media pembelajaran.
\end{abstract}

Kata Kunci: Lembar Kerja Siswa berbasis CAT, Kemampuan Pemahaman Matematis.

\section{PENDAHULUAN}

Proses belajar merupakan suatu proses yang kompleks yang terjadi pada diri setiap orang sepanjang hidupnya, proses belajar itu terjadi karena adanya interaksi antara seseorang dengan lingkungannya. Oleh karena itu, belajar dapat terjadi dimana saja dan kapan saja. Salah satu pertanda bahwa seseorang itu telah belajar adalah dengan adanya perubahan tingkat pengetahuan, keterampilan dan sikapnya. Dalam hal ini, matematika juga perlu dipelajari karena dapat menambah tingkat pengetahuan, keterampilan, sikap terhadap belajar siswa.

Pembelajaran yang berkualitas sangat tergantung dari motivasi pelajar dan kreatifitas pengajar. Desain pembelajaran yang baik, ditunjang fasilitas yang 
memandai, ditambah dengan kreatifitas guru akan membuat peserta didik lebih mudah mencapai target belajar. Pada kenyataan di lapangan proses pembelajaran yang dilaksanakan pada saat ini belum memenuhi harapan para guru sebagai pengembangan strategi pembelajaran di kelas. Siswa mengalami kesulitan dalam belajar matematika, khususnya dalam menyelesaikan soal yang berhubungan dengan kemampuan pemahaman matematis siswa. Menurut Sumarto (dalam Susanto, 2013:210), sedikitnya seseorang harus mengetahui lima aspek penting, yaitu: a) objek itu sendiri, b) relasinya dengan objek lain yang sejenis, c) relasinya dengan objek lain yang tidak sejenis, d) relasi-dual dengan objek lainnya yang sejenis, dan e) relasi dengan objek dalam teori lainnya. Dilihat dari jenisnya, menurut Russefendi ( dalam Susanto 2013:210), mengemukakan ada tiga macam pemahaman matematis, yaitu: pengubahan (translation), pemberian arti (interpretation), dan pembuatan ekstralasi (extrapolation). Bloom mengklarifikasi pemahaman ke dalam jenjang kognitif kedua yang menggambarkan suatu pengertian, sehingga seseorang mengetahui bagaimana berkomunikasi dan mengemukakan idenya untuk berkomunikasi. Dalam pemahaman tidak hanya sekedar memahami sebuah informasi tetapi termasuk juga keobjektifan, sikap, dan makna yang terkandung dari sesuatu informasi. Dengan kata lain, seseorang dapat mengubah suatu informasi yang ada dalam pikirannya ke dalam bentuk lain yang lebih berarti. Adapun menurut Skem ( dalam Susanto 2013:211), pemahaman dapat dibedakan menjadi dua jenis, yaitu pemahaman instrumental dan relasional. Menurut Anderson \& Krathwohl (2001) membagi menjadi tujuh kategori proses kognitif pemahaman diantaranya: menafsirkan (interpreting), memberikan contoh (exemplifying), mengklasifikasikan (classifying), meringkas (summarizing), menarik inferensi (inferring), membandingkan (comparing), dan menjelaskan (explaining).

Lembar Kerja Peserta Didik adalah sumber belajar penunjang yang dapat meningkatkan pemahaman siswa mengenai materi yang harus mereka kuasai (Senam, 2008). LKPD merupakan alat bantu untuk menyampaikan pesan kepada siswa yang digunakan oleh guru dalam proses pembelajaran. Melalui LKPD ini akan memudahkan guru dalam menyampaikan materi pembelajaran dan mengefektifkan waktu, serta akan menimbulkan interaksi antara guru dengan siswa dalam proses pembelajaran. Menurut Sriyono (1992), LKPD adalah salah satu bentuk program yang berlandaskan atas tugas yang harus diselesaikan dan berfungsi sebagai alat untuk mengalihkan pengetahuan dan keterampilan sehingga mampu mempercepat tumbuhnya minat siswa dalam mengikuti proses pembelajaran. Penggunaan media LKPD ini diharapkan dapat memberikan manfaat dalam proses pembelajaran, hal ini seperti yang dikemukakan oleh Arsyad (2005) antara lain yaitu :1) Memperjelas penyajian pesan dan informasi sehingga proses belajar semakin lancar dan dapat meningkatkan hasil belajar, 2) Meningkatkan motivasi siswa dengan mengarahkan perhatian siswa, sehingga memungkinkan siswa be-lajar sendiri sesuai dengan kemampuan dan minatnya, 3) Penggunaan media da-pat mengatasi keterbatasan indera, ruang, dan waktu, 4) Siswa akan mendapat-kan pengalaman yang sama mengenai suatu peristiwa dan memungkinkan terjadi-nya interaksi langsung dengan lingkungan sekitar. Tidak hanya itu melalui LKS, diharapkan siswa dapat termotivasi dalam mem-pelajari konsep-konsep kimia khususnya pada materi larutan penyangga.

Pada proses pembelajaran, LKPD digunakan sebagai sarana pembelajaran untuk menuntun siswa mendalami materi dari suatu materi pokok atau submateri pokok mata pelajaran yang telah atau sedang dijalankan. Melalui LKPD harus mengemukakan pendapat dan mampu mengambil kesimpulan. Computer Assisted Test didefinisikan sebagaisuatu metode ujian dengan menggunakan alat bantu komputer yang digunakan 
untuk mendapatkanstandar minimal kompetensi dasar maupun standar kompetensi kepegawaian (Sutrisno, 2014).Adapun tahapan proses dalam perancangan sistem CAT diawali denganpenelitian dan pengumpulan data, kemudian perencanaan, pembuatan prototipe,pelaksanaan uji coba, dan diikuti perbaikan dan pengembangan. Protipe sistem CAT mempunyai karakteristik sebagai berikut:(1) Aplikasi menggunakan platform windowsatau open sourceyang berbasis website; (2)Adanya narasi yang berisi petunjuk yangdisajikan pada layar monitor komputer; (3) Aplikasi disertai video gerakan mouseuntuk memudahkan penggunadalam mengoperasikannya, dan (4) Dilengkapi tutorialdan teks yang berisi petunjukpada layar monitor komputer agar semua peserta tes mudah dalam mengoperasikannya. Menurut Sutrisno (2014),CAT sebagai salah satu metode yang digunakan dalam pelaksanaan tes mempunyai prinsip dasar sebagai berikut; (1) Sistem CAT dirancangsemudah mungkin,sehingga peserta tes dapat mengoperasikannnya;(2) Cara mengoperasikan sangat mudah, bahkan bagi pemula sekalipun karena hanya dengan menggunakan mouseuntuk mengerjakan soal tes dan memilih jawaban. Panitiawajib memberikan pengarahan dan menayangkan video petunjuk cara pengoperasian sistem CAT untuk memberipetunjuk penggunaan sistem CAT; (3) Soal yang ada dalam aplikasi CAT bervariasi namun dengan tingkat kesulitan yang setara. Peserta mendapatkan soal berbeda, dan soal diacak secara otomatis kemudian didistribusikan kemasing-masing komputer peserta; dan (4) Pemeriksaan hasil tes langsung dilakukan oleh aplikasi secara otomatis. Nilai peserta dapat dipantau secara bersamaan melalui ruang monitoring di luar tempat pelaksanaantes.Smentara pesertatesdapat mengetahui nilai yang diperoleh sesaat setelah menyelesaikan ujian melalui layar monitor masing-masing computer.

Lembar Kerja Peserta Didik (LKPD) dapat digunakan sebagai pengajaran sendiri, mendidik siswa untuk mandiri, percaya diri, disiplin, bertanggung jawab dan dapat mengambil keputusan. LKPD dalam kegiatan belajar mengajar dapat dimanfaatkan pada tahap penanaman konsep (menyampaikan konsep baru) atau pada tahap penanaman konsep (tahap lanjutan dari penanaman konsep). Pemanfaatan LKPD pada tahap pemahaman konsep berarti LKPD dimanfaatkan untuk mempelajari suatu topik yang telah dipelajari pada tahap sebelumnya yaitu penanaman konsep. Tujuan LKPD; Memberikan pengalaman kongkret bagi siswa, Membantu variasi belajar, Membangkitkan minat siswa, Meningkatkan retensi belajar mengajar, Memanfaatkan waktu secara efektif dan efisien.

Menurut James (dalam Ruseffendi 1992:27) mengemukakan bahwa Matematika adalah ilmu mengenai bentuk, susunan, besaran dan konsep-konsep yang saling berhubungan satu sama lainnya dengan jumlah yang banyaknya terbagi kedalam tiga bidang, yaitu aljabar, analisis, dan geometri. Menurut Reys (dalam Ruseffendi 1992:28) mengemukakan bahwa matematika adalah telaahan tentang pola dan hubungan suatu jalan atau pola berpikir suatu seni, suatu bahasa, dan suatu alat.Menurut Karim, dkk (1997) mengemukakan tujuan diberikannya matematika pada jenjang pendidikan dasar pada hakekatnya dapat dibagi menjadi dua bagian yaitu tujuan umum dan tujuan khusus. Menurut Ruseffendi (1992) mengemukakan bahwamanfaat Matematika bagi umat manusia adalah 1) dengan belajar Matematika, manusia dapat menyelesaikan persoalan yang ada dimasyarakat yaitu dalam berkomunikasi sehari-hari seperti dapat berhitung, 2) matematika diajarkan di sekolah karena matematika dapat membantu bidang studi lain, 3) dengan mempelajari geometri ruang, siswa dapat meningkatkan kemampuan pemahaman ruang sehingga berpikir logis dan tepat di dimensi tiga, 4) dapat di pakai sebagai alat ramal/perkiraan seperti prakiraan cuaca, pertumbuhan penduduk, keberhasilan belajar, dan lain-lain, 5) 
sebagai penunjang pemakaian alat-alat canggih seperti kalkulator, dan komputer, 6) untuk terpeliharanya matematika itu sendiri demi peningkatan kebudayaan.

Penggunaan media dalam pembelajaran matematika sangat diperlukan karena media mempunyai kelebihan kemampuan teknis, mampu menyajikan kelebihan suatu peristiwa secara nyata, terpadu atau menyajikan konsep utuh dan benar serta menjadi saluran atau perantara dalam menyampaikan pesan kepada peserta didik. Guru juga diharapkan dapat menggunakan media pembelajaran yang sesuai dengan keadaan siswa agar dapat meningkatkan hasil belajar siswa pada semua mata pelajaran salah satu diantaranya dengan menggunakan LKPD berbasis CAT (Computer Assited Tes)yang dikelola dari software macromedia flash. Macromedia flash merupakan cara belajar yang efektif, efesien, dan menyenangkan. Sehingga dapat memberikan pengalaman-pengalaman nyata yang dapat merangsang siswa dapat meningkatkan hasi belajar siswa. Untuk menyikapi permasalahan yang timbul dalam proses pembelajaran, pengembangan LKPD Berbasis CAT (Computer Assited Test) untuk meningkatkan kemampuan pemahaman matematis siswa.

\section{METODE PENELITIAN}

Jenis Penelitian

Penelitian ini termasuk dalam penelitian dan pengembangan (Research and Development). Sebagaimana pendapat Sugiyono (2010) bahwa R\&D adalah metode penelitian yang digunakan untuk menghasilkan produk tertentu dan menguji keefektifan produk tersebut. Metode ini digunakan dengan tujuan mengembangan lembar kerja peserta didik berbasis CAT siswa kelas VI SD Methodist-12 Medan pada materi operasi hitung bilangan bulat.

\section{Lokasi Penelitian}

Penelitian ini dilaksanakan di SD Swasta Methodist 12 Medan, terletak di Jl.Panca No. 28 Marendal Kelurahan Harjoasi II, Kecamatan Medan Amplas.

\section{Subjek dan Objek Penelitian}

Subjek dari penelitian ini adalah kelas VI SD Swasta Methodist 12 Medan Tahun Ajaran 2019/2020. Objek penelitian ini adalah lembar kerja peserta didik berbasis CAT Variabel Penelitian.

Adapun variabel dalam penelitian ini adalah sebagai berikut :

1. Validitas ketepatan materi pembelajaran matematika pada kelas VI terkait materi operasi hitung bilangan bulat.

2. Validitas ketepatan desain instruksional

3. Validitas ketepatan lembar kerja peserta didik berbasis CAT.

4. Kemampuan pemahaman matematis siswa yang diukur dengan tes uraian terkait materi operasi hitung bilangan bulat.

5. Tanggapan siswa terhadap lembar kerja peserta didik berbasis CAT terkait materi operasi hitung bilangan bulat.

6. Tanggapan guru terhadap lembar kerja peserta didik berbasis CAT terkait materi operasi hitung bilangan bulat.

\section{Model Pengembangan}

Pengembangan media pembelajaran matematika adalah suatu proses untuk menentukan atau menciptakan suatu kondisi tertentu yang menyebabkan siswa dapat berinteraksi sehingga terjadi perubahan tingkah laku. Salah satu model yang sesuai untuk mengembangkan media pembelajaran adalah model pembelajaran 4-D.

Model pengembangan perangkat 4-D terdiri dari 4 tahap pengembangan yaitu Define, Design, Develop dan Disseminate atau diadaptasikan menjadi model 4-D yaitu 
pendefinisian, perancangan, pengembangan dan penyebaran dalam Rochmad (2012:67).

Modifikasi dari tahap-tahap pengembangan media pembelajaran dapat dilihat pada gambar 4.1 berikut :

Tabel 1. Modifikasi Model Pengembangan Media Pembelajaran 4-D

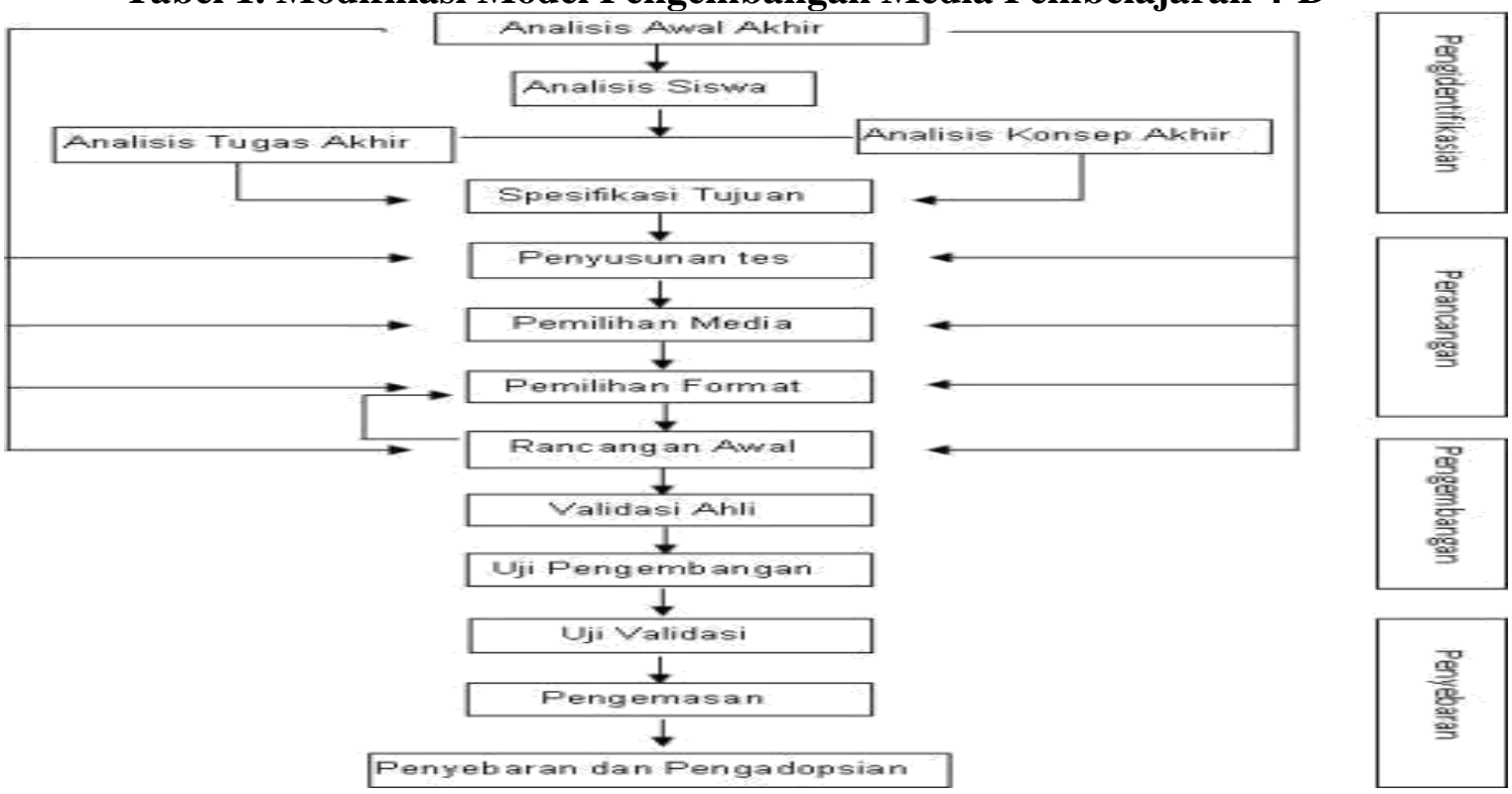

\section{Instrumen Pengumpulan Data}

Instrumen pengumpulan data yang digunakan sebagai berikut:

a. Lembar Angket Penilaian

Lembar angket dalam penelitian ini adalah lembar penilaian atau saran terhadap produk atau media pembelajaran untuk penyempurnaan media yang dihasilkan dalam pelaksanaan penelitian. Adapun lembar angket terdiri dari :

1. Lembar angket untuk ahli materi yaitu penilaian terhadap kualitas materi pembelajaran dan pengembangan aspek sistem penyampaian pembelajaran

2. Lembar angket untuk ahli desain instruksional pembelajaran yaitu penilaian terhadap kualitas desain pembelajaran dan teknis dari media pembelajaran

3. Lembar angket untuk ahli media yaitu kualitas rekayasa perangkat lunak (software) yang dikembangkan khususnya media pembelajaran

4. Lembar angket untuk siswa yaitu tanggapan terhadap penggunaan dan manfaat media pembelajaran yang dikembangkan

5. Lembar angket persepsi guru yaitu tanggapan guru terhadap penggunaan dan manfaat media pembelajaran yang dikembangkan

\section{Ujicoba Instrumen Tes}

\section{Validitas Tes}

Untuk mengukur tes digunakan korelasi Product Moment Pearson (Arikunto, 2009:72) dengan mengkorelasikan antara skor yang didapat siswa pada suatu butir soal dengan skor total. Rumus yang digunakan adalah :

$$
\mathrm{Rxy}=\frac{N \Sigma x y-(\Sigma x)(\Sigma y)}{\sqrt{\left(N \Sigma X^{2}-\Sigma X\right)^{2}\left(N \Sigma Y^{2}-\Sigma Y\right)^{2}}} \quad \text { (Arikunto, 2014: 231) }
$$

Keterangan :

Rxy = Koefisien korelasi $\mathrm{x}$ dan $\mathrm{y}$

$\mathrm{N} \quad=$ Jumlah responden / banyak siswa peserta tes

$\mathrm{X}=$ Jumlah skor diperoleh siswa untuk tiap item soal 
Y = Jumlah skor total yang benar

Untuk mengetahui signifikansi korelasi yang didapat, diuji dengan rumus $\mathrm{t}$ :

$t=r_{x y} \sqrt{\frac{N-2}{1-\left(r_{x y}\right)^{2}}}$

Dengan;

$\mathrm{t} \quad=$ daya beda uji $\mathrm{t}$

$\mathrm{N}=$ jumlah subjek

$r_{x y}=$ koefisien krelasi antara skor butir dengan skor total

Menentukan validitas suatu butir soal. Kriteria yang harus dipenuhi agar suatu butir soal dikatakan valid adalah jika $t_{\text {hitung }}>t_{\text {tabel }}$ dengan $t_{\text {tabel }}=t_{(1-\alpha)(d k)}$ untuk $\mathrm{dk}=N-2$ dan (taraf signifikansi) dipilih 5\%.

Untuk menginterpetasikan koefisien reliabilitas suatu alat evaluasi (Arikunto, 1999) memberikan kriteria sebagai berikut:

Tabel 2. Kriteria Uji Validitas Tes

\begin{tabular}{cc}
\hline $0,80-1,00$ & Sangat tinggi \\
\hline $0,60-0,79$ & Tinggi \\
\hline $0,40-0,59$ & Cukup \\
\hline $0,20-0,39$ & Rendah \\
\hline $0,00-0,19$ & Sangat rendah \\
\hline
\end{tabular}

\section{Reliabilitas Tes}

Realiabilitas instrumen tes dihitung untuk mengetahui ketetapan hasil tes.

Untuk menghitung reliabilitas butir tes ini digunakan rumus yang sesuai dengan bentuk tes uraian (essay), yaitu rumus alpha sebagai berikut:

$$
\mathrm{R} 11=\left(\frac{n}{n-1}\right)\left(\frac{s^{2}-\Sigma p q}{s^{2}}\right) \quad \text { (Arikunto, 2016: 115) }
$$

Keterangan :

\begin{tabular}{|c|c|}
\hline R11 & $=$ Reliabilitas tes \\
\hline $\mathrm{p}$ & $=$ Proporsi subjek yang menjawab item dengan benar \\
\hline $\mathrm{q}$ & $=$ Proporsi subjek yang menjawab item dengan salah \\
\hline$\Sigma \mathrm{pq}$ & $=$ Jumlah hasil perkalian antara $\mathrm{p}$ dan $\mathrm{q}$ \\
\hline $\mathrm{n}$ & $=$ Banyak nya item \\
\hline $\mathrm{S}$ & $=$ Standar deviasi \\
\hline
\end{tabular}

Rumus untuk mencari standar deviasi sebagai berikut :

$$
\mathrm{SD}=\sqrt{\frac{\Sigma f x^{2}}{N}}
$$

Keterangan :

$$
\begin{array}{ll}
\mathrm{SD} & =\text { Standar Deviasi } \\
\Sigma \mathrm{fx}^{2} & =\text { jumlah perkalian antara frekuensi masing }- \text { masing interval } \\
& \text { dengan frekuensi yang dikuadratkan } \\
\mathrm{N} & =\text { jumlah sampel }
\end{array}
$$

Interpretasi nilai $\mathrm{r}_{11}$ mengacu pada Jihad dan Haris (2012: 180) dipaparkan pada tabel 3.7 .

Tabel 3. Kualifikasi Koefisien Korelasi

No Koefisien Korelasi $\quad$ Kualifikasi




\begin{tabular}{lll}
\hline 1 & $0,80<\mathrm{r}_{\mathrm{xy}} \leq 1,00$ & Derajat sangat tinggi \\
\hline 2 & $0,60<\mathrm{r}_{\mathrm{xy}} \leq 0,80$ & Derajat tinggi \\
\hline 3 & $0,40<\mathrm{r}_{\mathrm{xy}} \leq 0,60$ & Derajat cukup \\
\hline 4 & $0,20<\mathrm{r}_{\mathrm{xy}} \leq 0,40$ & Derajat rendah \\
\hline 5 & $\mathrm{r}_{\mathrm{xy}} \leq 0,40$ & Derajat sangat rendah \\
\hline
\end{tabular}

\section{Teknik Analisa Data}

Teknik analisis data dalam penelitian ini sebagai berikut :

\section{Validasi Media}

\section{Validasi Ahli}

Analisis data dalam penelitian ini menggunakan analisis deskriptif kuantitatif. Selanjutnya dari data yang diperoleh hasilnya dirata-rata dan digunakan untuk menilai kualitas produk yang dikembangkan. Kriteria produk akan dikonversikan menjadi nilai dengan skala lima menggunakan Skala Likert yang dianalisis secara deskriptif (skor rata-rata dan persentase) yaitu menghitung persentase indikator dari setiap kategori pada media Lectora Inspire yang telah dikembangkan dengan menggunakan rumus :

Skor empiris $=\frac{\text { Jumlah Skor yang diperoleh }}{\text { Jumlah skor ideal seluruh item }} \times 100 \%$

Selanjutnya persentase kriteria validitas dapat dilihat pada Tabel.

Tabel 4. Persentase Kriteria Kesesuaian Indikator

\begin{tabular}{lccc}
\hline No & Kriteria & $\begin{array}{c}\text { Interval } \\
\text { Persentase }\end{array}$ & Keterangan \\
\hline 1. & Sangat baik & $85 \% \leq \mathrm{X} \leq 100 \%$ & Tidak perlu revisi \\
\hline 2. & Baik & $75 \% \leq \mathrm{X} \leq 84 \%$ & Tidak perlu revisi \\
\hline 3. & Sedang & $65 \% \leq \mathrm{X} \leq 74 \%$ & Direvisi \\
\hline 4. & Kurang & $55 \% \leq \mathrm{X} \leq 64 \%$ & Direvisi \\
\hline 5. & Sangat kurang baik & $0 \% \leq \mathrm{X} \leq 54 \%$ & Direvisi \\
\hline
\end{tabular}

Sedangkan dalam perhitungan tingkat kelayakan pada media macromedia flash sebagai media pembelajaran, penilaiannya sebagai berikut :

Tabel 5. Persentase Kriteria Tingkat Kelayakan

\begin{tabular}{lcc}
\hline No & Tingkat Kelayakan & Skor \\
\hline 1. & Tidak layak & $<65 \%$ \\
\hline 2. & Kurang layak & $65 \%-74 \%$ \\
\hline 3. & Layak & $75 \%-84 \%$ \\
\hline 4. & Sangat layak & $85 \%-100 \%$ \\
\hline
\end{tabular}

\section{Tanggapan Guru dan Siswa}

Data mengenai tanggapan guru dan siswa terhadap media macromedia flash sebagai media pembelajaran yang dikembangkan, diberikan angket setelah selesai pembelajaran materi pecahan. Kriteria penilaian kesesuaian dengan indikator tanggapan guru dan siswa terhadap media macromedia flash sebagai media pembelajaran dapat dilihat pada tabel 4.3 berikut :

Tabel 6. Persentase Kriteria Tanggapan Guru dan Siswa sesuai Indikator

\begin{tabular}{llll}
\hline No & Kriteria & Interval & Keterangan \\
\hline
\end{tabular}




\begin{tabular}{lccc}
\hline & & Persentase & \\
\hline 1. & Sangat baik & $85 \% \leq \mathrm{X} \leq 100 \%$ & Tidak perlu revisi \\
\hline 2. & Baik & $75 \% \leq \mathrm{X} \leq 84 \%$ & Tidak perlu revisi \\
\hline 3. & Sedang & $65 \% \leq \mathrm{X} \leq 74 \%$ & Direvisi \\
\hline 4. & Kurang & $55 \% \leq \mathrm{X} \leq 64 \%$ & Direvisi \\
\hline 5. & Sangat kurang baik & $0 \% \leq \mathrm{X} \leq 54 \%$ & Direvisi \\
\hline
\end{tabular}

\section{Validasi RPP}

Validasi RPP dilakukan berdasarkan pada 3 aspek penilaian yaitu format, bahasa dan isi. Persentase rata-rata skor untuk validasi RPP dapat dilihat pada tabel 4.4 berikut :

Tabel 7. Persentase Skor Rerata Validasi RPP

\begin{tabular}{lccc}
\hline No & Kriteria & $\begin{array}{c}\text { Interval } \\
\text { Persentase }\end{array}$ & Keterangan \\
\hline 1. & Sangat baik & $85 \% \leq \mathrm{X} \leq 100 \%$ & Tidak perlu revisi \\
\hline 2. & Baik & $75 \% \leq \mathrm{X} \leq 84 \%$ & Tidak perlu revisi \\
\hline 3. & Sedang & $65 \% \leq \mathrm{X} \leq 74 \%$ & Direvisi \\
\hline 4. & Kurang & $55 \% \leq \mathrm{X} \leq 64 \%$ & Direvisi \\
\hline 5. & Sangat kurang baik & $0 \% \leq \mathrm{X} \leq 54 \%$ & Direvisi \\
\hline
\end{tabular}

\section{Peningkatan Kemampuan Pemahaman Matematis Siswa}

Untuk mengetahui peningkatan kemampuan pemahaman matematis siswa dilakukan tes awal (pretest) dan tes akhir (posttest). Hasil dari kedua tes tersebut dihitung dengan $\mathrm{N}$-gain :

$$
(g)=\frac{(\text { gain })}{(\text { gain })_{\text {Max }}}=\frac{(\text { postest })-(\text { pretest })}{100-(\text { pretest })}
$$

Kriteria peningkatan ditentukan sebagai berikut :

Tabel 8. Kriteria peningkatan

\begin{tabular}{cc}
\hline $\mathrm{g}<0,3$ & Kategori Rendah \\
\hline $0,3 \leq \mathrm{g} \leq 0,7$ & Kategori Sedang \\
\hline $\mathrm{g} \geq 0,7$ & Kategori Tinggi \\
\hline
\end{tabular}

\section{HASIL DAN PEMBAHASAN}

\section{Analisis Data Penilaian Ahli Materi}

Penilaian ahli materi dalam penelitian ini dilakukan oleh satu orang validator dalam bidang pendidikan matematika. Adapun aspek dalam penilaian yaitu kelayakan isi, penyajian, kebahasaan dan kegrafikan. Penilaian Ahli Materi terhadap lembar kerja peserta didik berbasis CAT bahwa penilaian ahli materi dalam penelitian ini dilakukan oleh satu orang validator dalam bidang pendidikan matematika. Adapun aspek dalam penilaian yaitu kelayakan isi, penyajian, kebahasaan dan kegrafikan. Hasil dari penilaian ahli materi bahwa aspek Kelayakan Isi sebesar $98.75 \%$, Penyajian sebesar $86.67 \%$, Kebahasaan sebesar $86.67 \%$ dan Kegrafikan sebesar $80 \%$. Nilai rata-rata dari keempat aspek tersebut sebesar $88.02 \%$ dalam kategori Sangat Baik.

Penilaian Ahli Desain Instruksional terhadap lembar kerja peserta didik berbasis CAT bahwa Penilian ahli media bahwa bahwa aspek Kelayakan media sebesar 93.33\%, Kelayakan isi sebesar 96.25\%, Penyajian sebesar 93.33\%, dan Kegrafikan $80.00 \%$. Keempat aspek tersebut dalam kategori Sangat Baik. Nilai rata-rata dari kedua aspek tersebut sebesar $90.73 \%$ dalam kategori Sangat Baik. Penilaian Ahli 
Media terhadap lembar kerja peserta didik berbasis CAT bahwa bahwa aspek Kelayakan media sebesar $90.00 \%$ dan Kelayakan isi sebesar 97.50\%, Penyajian sebesar $97.50 \%$. Ketiga aspek tersebut dalam kategori Sangat Baik. Nilai rata-rata dari kedua aspek tersebut sebesar 95.00\% dalam kategori Sangat Baik.

\section{Analisis Data Tanggapan Siswa Uji Perorangan}

Tanggapan siswa dalam penelitian ini dilakukan oleh satu orang siswa kelas V SD. Adapun aspek dalam tanggapan siswa untuk uji perorangan yaitu isi, tujuan, kelayakan, kualitas teknik dan daya tarik.

Penilaian Tanggapan Siswa Uji Perorangan terhadap lembar kerja peserta didik berbasis cat bahwa tanggapan siswa dalam penelitian ini dilakukan oleh satu orang siswa kelas VI SD. Adapun aspek dalam tanggapan siswa untuk uji perorangan yaitu isi, tujuan, kelayakan, kualitas teknik dan daya tarik. Hasil analisis data tanggapan siswa uji perorangan bahwa aspek Isi sebesar $100.00 \%$, tujuan sebesar $100.00 \%$, kelayakan sebesar 93,33\%, kualitas teknik sebesar $95.00 \%$ dan daya tarik sebesar 930.00\%. Kelima aspek tersebut dalam kategori Sangat Baik. Nilai rata-rata dari kelima aspek tersebut sebesar 92.00\% dalam kategori Sangat Baik.

\section{Analisis Data Tanggapan Siswa Uji Kelompok Kecil}

Tanggapan siswa dalam penelitian ini dilakukan oleh enam orang siswa kelas V SD. Adapun aspek dalam tanggapan siswa untuk uji perorangan yaitu isi, tujuan, kelayakan, kualitas teknik dan daya tarik. Penilaian Tanggapan Siswa terhadap lembar kerja peserta didik berbasis CAT pada Uji Coba Kelompok Kecil dapat dipahami bahwa Tanggapan siswa dalam penelitian ini dilakukan oleh 6 orang siswa kelas VI SD. Adapun aspek dalam tanggapan siswa untuk uji perorangan yaitu isi, tujuan, kelayakan, kualitas teknik dan daya tarik. Hasil analisis data tanggapan siswa uji perorangan bahwa aspek Isi pembelajaran sebesar 93.33\%, tujuan sebesar 93.33\%, kelayakan sebesar $91.11 \%$, kualitas teknik sebesar $90.00 \%$ dan daya tarik sebesar 92.50\%. Kelima aspek tersebut dalam kategori Sangat Baik. Nilai rata-rata dari kelima aspek tersebut sebesar $92.00 \%$ dalam kategori Sangat Baik.

\section{Analisis Data Tanggapan Siswa Uji pada Uji Lapangan}

Tanggapan siswa dalam penelitian ini dilakukan oleh 25 orang siswa kelas V SD. Adapun aspek dalam tanggapan siswa untuk uji perorangan yaitu isi, tujuan, kelayakan, kualitas teknik dan daya tarik. Penilaian Tanggapan Siswa terhadap lembar kerja peserta didik berbasis CAT pada Uji Coba Lapangan bahwa Tanggapan siswa dalam penelitian ini dilakukan oleh 34 orang siswa kelas VI SD. Adapun aspek dalam tanggapan siswa untuk uji perorangan yaitu isi, tujuan, kelayakan, kualitas teknik dan daya tarik. Hasil analisis data tanggapan siswa uji lapangan bahwa aspek Isi sebesar $98.08 \%$, tujuan sebesar 96,08\%, kelayakan sebesar 93.92\%, kualitas teknik sebesar 92.65\% dan daya tarik sebesar 95.15\%. Kelima aspek tersebut dalam kategori Sangat Baik. Nilai rata-rata dari kelima aspek tersebut sebesar 94.77\% dalam kategori Sangat Baik.

\section{Analisis Data Tanggapan Guru}

Tanggapan guru dalam penelitian ini dilakukan oleh dua orang yaitu guru kelas V dan guru mata pelajaran matematika di SD Methodist-12 Medan. Adapun aspek dalam tanggapan guru yaitu isi, tujuan, kelayakan, kualitas teknik dan daya tarik. Penilaian Tanggapan Guru terhadap lembar kerja peserta didik berbasis CAT bahwa tanggapan guru dalam penelitian ini dilakukan oleh seorang orang yaitu guru kelas VI dan guru mata pelajaran matematika di SD Methodist 12 Medan. Adapun aspek dalam tanggapan guru yaitu isi, tujuan, kelayakan, kualitas teknik dan daya tarik. Hasil analisis data tanggapan siswa uji perorangan bahwa aspek Isi sebesar 93.33\%, tujuan 
sebesar $100.00 \%$, kelayakan sebesar $86.67 \%$, kualitas sebesar $90.00 \%$ dan daya tarik sebesar $90.00 \%$. Kelima aspek tersebut dalam kategori Sangat Baik. Nilai rata-rata dari kelima aspek tersebut sebesar 92.00\% dalam kategori Sangat Baik.

\section{Analisis Data Peningkatan Kemampuan Pamahaman Matematis Siswa}

Data peningkatan kemampuan pemahaman matematis siswa ditinjau dari ujicoba lapangan dapat dilihat pada Tabel berikut :

Tabel 9. Data Pretes-Postes Ujicoba Lapangan

\begin{tabular}{cccc}
\hline & PRETES & POSTES & GAIN \\
\hline MIN & 35 & 65 & 0.5 \\
\hline MAX & 85 & 95 & 0.7 \\
\hline ST.DEV & 9.4 & 3.8 & \\
\hline RERATA & 53.6 & 89 & 0.8 \\
\hline
\end{tabular}

Berdasarkan table diperoleh nilai rata-rata pretes yaitu 53.60 sedangkan nilai rata-rata postes yaitu 89.0. Peningkatan rata-rata sebesar 35.4. Nilai gain minimal sebesar 0,5 sedangkan nilai gain maksimal sebesar 0.7 . Nilai rata-rata gain data kemampuan pemahaman matematis siswa pada ujicoba lapangan sebesar 0,8 (kategori Tinggi).

Data peningkatan kemampuan pemahaman matematis siswa ditinjau dari penyebaran dapat dilihat pada Tabel berikut :

Tabel 10. Data Pretes-Postes Penyebaran

\begin{tabular}{cccc}
\hline & PRETES & POSTES & GAIN \\
\hline MIN & 35 & 65 & 0,5 \\
\hline MAX & 65 & 80 & 0,8 \\
\hline ST.DEV & 8.8 & 4.5 & \\
\hline RERATA & 54.1 & 88.7 & 0,8 \\
\hline
\end{tabular}

Tabel 11. Correlations

\begin{tabular}{|c|c|c|c|}
\hline & & $\begin{array}{c}\text { KemampuanPe } \\
\text { mahamanMate } \\
\text { matis }\end{array}$ & $\begin{array}{l}\text { LKPDBerbasis } \\
\text { CAT }\end{array}$ \\
\hline \multirow{5}{*}{$\begin{array}{l}\text { KemampuanPemahamanM } \\
\text { atematis }\end{array}$} & Pearson Correlation & 1 & $.97^{* *}$ \\
\hline & Sig. (2-tailed) & & .000 \\
\hline & $\begin{array}{l}\text { Sum of Squares and Cross- } \\
\text { products }\end{array}$ & 665.44 & 623.24 \\
\hline & Covariance & 20.17 & 18.89 \\
\hline & $\mathrm{N}$ & 34 & 34 \\
\hline \multirow[t]{5}{*}{ LKPDBerbasisCAT } & Pearson Correlation & $.97^{* *}$ & $\overline{1}$ \\
\hline & Sig. (2-tailed) & .000 & \\
\hline & $\begin{array}{l}\text { Sum of Squares and Cross- } \\
\text { products }\end{array}$ & 623.24 & 627.06 \\
\hline & Covariance & 18.89 & 19.00 \\
\hline & $\mathrm{N}$ & 34 & 34 \\
\hline
\end{tabular}


Dari Tabel 11. diperoleh korelasi antara LKPD berbasis CAT dengan kemampuan pemahaman matematis siswa adalah 0,97. Hal ini menunjukkan bahwa terjadi hubungan yang kuat antara LKPD berbasis CAT dengan kemampuan pemahaman matematis siswa. Sedangkan arah hubungan adalah positif karena nilai r positif, berarti semakin baik LKPD berbasis CAT yang dikembangkan maka semakin meningkatkan kemampuan pemahaman matematis siswa. Oleh karena nilai Signifikansi $(0,00<0,05)$ maka Ho ditolak, artinya bahwa ada hubungan secara signifikan antara LKPD berbasis CAT dengan kemampuan pemahaman matematis siswa. Karena koefisien korelasi nilainya positif, maka berarti LKPD berbasis CAT berhubungan positif dan signifikan terhadap kemampuan pemahaman matematis siswa.

Untuk mengetahui pengaruh LKPD berbasis CAT terhadap kemampuan pemahaman matematis siswa dapat dilihat pada Tabel 5.6 berikut:

Tabel 12. Model Summary

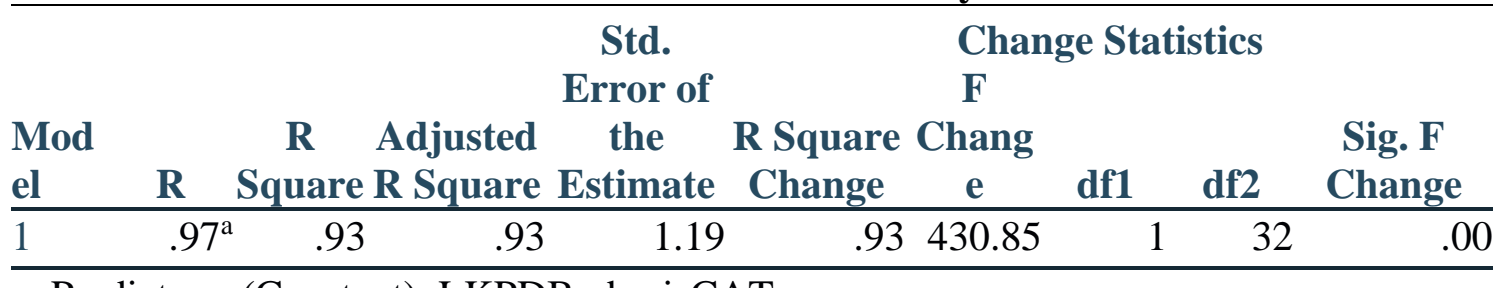

a. Predictors: (Constant), LKPDBerbasisCAT

Nilai R yang merupakan simbol dari nilai koefisien korelasi sebesar 0,965. Nilai ini dapat diinterpretasikan bahwa hubungan LKPD berbasis CAT dan kemampuan pemahaman matematis siswa kuat. Melalui tabel ini juga diperoleh nilai $R$ Square atau koefisien determinasi (KD) yang diperoleh adalah 93,1\% yang dapat diartikan bahwa variabel LKPD berbasis CAT memiliki pengaruh kontribusi sebesar 93,1\% terhadap kemampuan pemahaman matematis siswa dan $6.9 \%$ lainnya dipengaruhi oleh faktorfaktor lain diluar variabel LKPD berbasis CAT.

\section{DAFTAR PUSTAKA}

Anderson, L. W., \& Krathwohl, D. R. (Eds.) (2001). A taxonomy for learning, teaching, and assessing:A revision of Bloom's taxonomy of educational Objectives. New York: Longman.

Aprisya Krispriana, dkk (2016) Sistem Informasi Computer Assisted Test (CAT)Kementerian Agama Republik Indonesia.

Arsyad, Azhar. 2005. LKPD Pembelajaran. PT Raja Grafindo Persada: Jakarta.

Djorghy, Prabawati (2019) Implementasi Sistem Computer Assisted Test (CAT) Dalam Rangka Penjaringan Perangkat Desa Di Kedungpeluk Kecamatan Candi Kabupaten Sidoarjo.

Karim, Muchtar A. 1997. Pendidikan Matematika I. Depdikbud: Jakarta Lilis Nurliawaty (2017) Lembar Kerja Peserta Didik (LKPD) Berbasis Problem Solving Polya.

Russeffendy. 1992. Pendidikan Matematika 3. Jakarta: DEPDIKNAS

Senam, Arianingrum, R., Permanasari dan Suharto. 2008. Efektifitas Pembelajaran Kimia Untuk Siswa SMA Kelas XI dengan Menggunakan LKS Kimia Berbasis Life Skill. Jurnal Pendidikan Didaktika, 9 (3), 280-290.

Sri Latifah (2016) Pengembangan Lembar Kerja Peserta Didik (LKPD) Berorientasi Nilai-Nilai Agama Islam melalui Pendekatan Inkuiri Terbimbing pada Materi Suhu dan Kalor. 
Sriyono. 1992. Teknik Belajar Mengajar dalam CBSA. Jakarta:Rineka Cipta.

Sugiyono.2010. Metode Penelitian Kualitatif Kuantitatif dan R\&D. Bandung : Alfabeta

Susanto, Ahmad. 2013. Teori Belajar Pembelajaran. Jakarta: Kencanar

Sutrisno, Eko. 2014. CAT BKN Untuk Indonesia. Jakarta: BKN 